\title{
Deep concerns
}

\section{The United States' flagship underground laboratory is running into challenges over its relations with local Native Americans. Rex Dalton reports.}

Deep in South Dakota's Black Hills, engineers are halfway through pumping water from a 2.6-kilometre-deep mineshaft near the town of Lead. By 2015, US researchers hope, this watery hole will have dried out and become home to one of the country's biggest science infrastructure projects: the Deep Underground Science and Engineering Laboratory, or DUSEL.

But the US\$500-million plan has found one of its most difficult tasks on the surface. It has struggled to meet goals to work with local Native Americans, whose cooperation is vital to keeping the project on track. A federal review this year questioned whether DUSEL would create educational and outreach opportunities for local tribes; if not, it could face lawsuits, delays or other major problems.

Project leaders at the National Science Foundation (NSF), the Department of Energy and within South Dakota envision DUSEL as a major facility spinning off jobs for the local community. It landed in the state in 2007 after a hard-fought nationwide competition, lured in part by $\$ 120$ million from South Dakota, including $\$ 70$ million from local philanthropist Denny Sanford.

DUSEL will be built within North America's deepest gold mine, Homestake, where physicist Raymond Davis built his pioneering neutrino detector in the 1960s, 1.5 kilometres down. Today, DUSEL leaders plan to install one suite of scientific instruments near the site of that original neutrino work, and to add a second

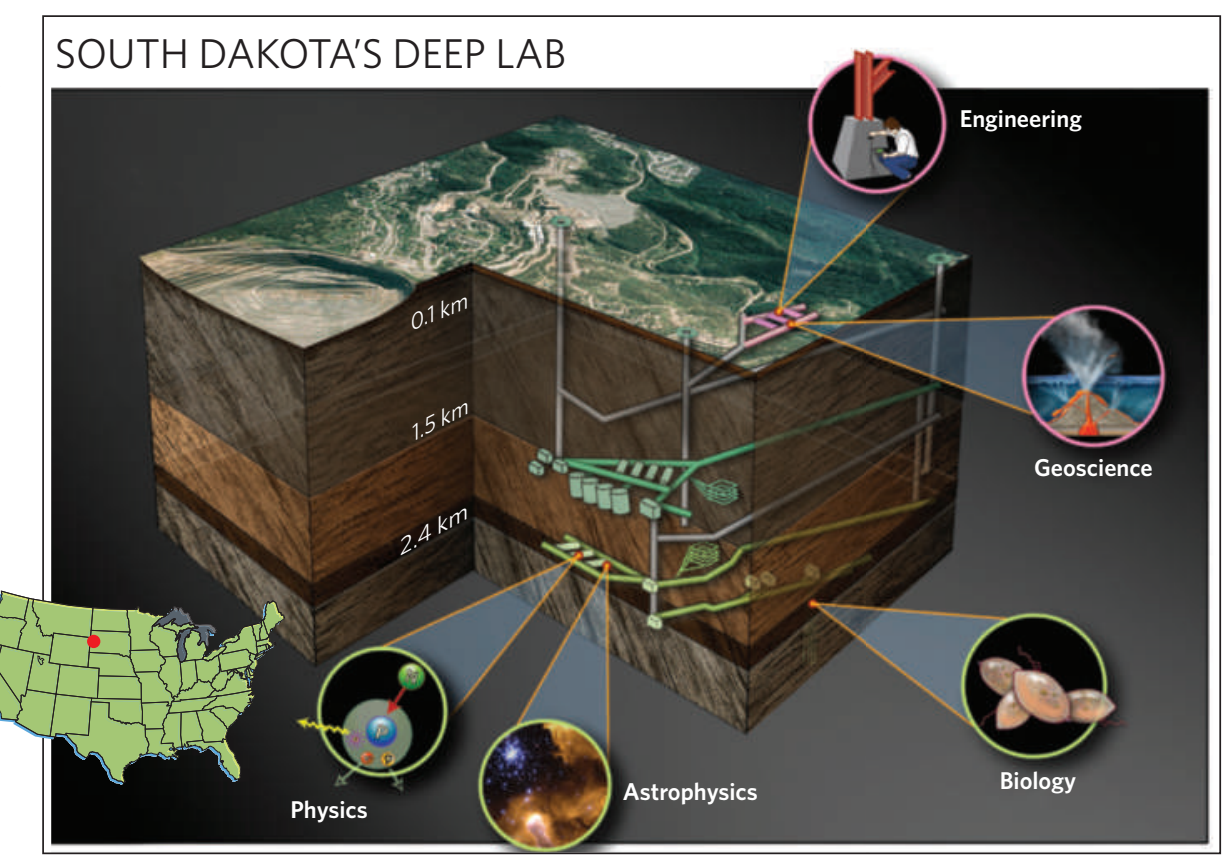

facility 2.4 kilometres down. The idea is to use the overlying rock to block cosmic rays, which can interfere with astrophysics experiments. The facility will join other such laboratories around the world, including the 2.1-kilometre-deep Sudbury Neutrino Observatory in Ontario, Canada, and Italy's 1.4-kilometre-deep Gran Sasso National Laboratory.

At DUSEL, the planned experiments include beaming neutrinos to Homestake from the Fermi National Accelerator Laboratory, 1,300 kilometres away in Batavia, Illinois. Detectors in the mine will look for evidence of neutrino oscillation, in which neutrinos change their 'flavour'. Other experiments would hunt for dark matter, study water flow at depth and investigate buried microbial life.

For instance, Tullis Onstott, a biogeologist at

\section{Sex scandal allegations surface at South Dakota school}

Allegations of the abuse of women students, cover-ups and retaliations have quietly simmered for years at the South Dakota School of Mines and Technology in Rapid City. The alleged offences include offering grades for sex, physical assault and videotaping of sexual sessions. Now the old allegations, and some new ones, raise questions about how the school will handle humanresource issues under its US\$1million-a-year subcontract for the Deep Underground Science and Engineering Laboratory (DUSEL).

In 2006, geology professor Gale Bishop sent a dossier to school executives describing more than a decade of alleged personnel violations. The executives have said the issues were investigated and found to be without base. But interviews with students and faculty members suggest the complaints weren't fully probed.

Bishop, now retired, sent the same dossier this March to the school's new president, Robert Wharton. Bishop says he did so because he was concerned that school palaeontologist Gerald Grellet-Tinner was being penalized for, among other issues, trying to help women students who had claimed harassment. Grellet-
Tinner was notified in March that his contract would not be renewed. Grellet-Tinner says he experienced professional and personal disagreements with longtime school palaeontologist James Martin, who is named in the 2006 dossier as allegedly being involved in sexual-harassment cases.

The dossier alleges Martin made 160 videotapes of himself in sexual sessions that included a woman from his field school and Julie Smoragiewicz, vice-president for public relations and admissions. The tape cache was discovered in 2000 by one of the women who was taped, the dossier says; three of the women then destroyed them. Nature confirmed these events with four former students or staff with direct knowledge.

Martin and Smoragiewicz declined to be interviewed. Former Earth sciences dean William Roggenthen, now the school's co-principal DUSEL investigator, says he learned of the allegations about four years ago, and required that staff and students be trained on sexual-harassment issues.

Roggenthen says he is unaware of any current issues. "It is my direct responsibility to make sure such inequities don't leak into the DUSEL project," he says.

R.D. 
Princeton University in New Jersey, is looking to DUSEL to understand how microbes function in rock fracture zones. "It is impossible to do this anywhere else; you have to get down there and do the experiments," he says.

Next month, the NSF will award up to $\$ 15$ million in three-year grants to develop experimental designs for DUSEL projects. In 2011, the agency will ask the National Science Board for preliminary design approval for the full thing. Department of Energy officials say they will seek at least $\$ 200$ million for complementary facilities.

But local Native American tribes are wary. Long ill-treated by the federal government, who seized the land for its gold more than a century ago and then polluted it with mine run-off, they are cautious about the new influx of government scientists. Physicists visited local powwows to stamp out rumours about Homestake being turned into a nuclear waste dump. Passion and bitterness still run strong, even among Native American scientists.

National project leaders have found themselves entangled in this history. "I'm very much in the learning mode," says Kevin Lesko, a physicist at Lawrence Berkeley National Laboratory

$\frac{ \pm}{\overleftarrow{ }}(\mathrm{LBNL})$ in California and the ড̛⿱ "We really want to understand the tribal colleges' perspective."

Last summer, LBNL scientists started a cultural advisory committee - the first significant outreach in five years to Native Americans - which has included four Native American scientists and engineers. "We understand we are working in lands that are sacred to Native Americans," says retired California physicist George Campbell, who chairs the committee.

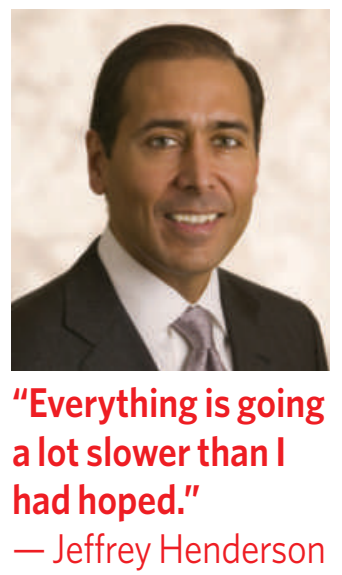

But Campbell has found himself facing a cultural chasm between the Native American community and the South Dakota School of Mines and Technology in Rapid City, which the LBNL has subcontracted to act as the main partner in DUSEL. The school, founded to train engineers shortly after Homestake opened in 1877, has only about 40 Native Americans among its 2,000 students, although $11 \%$ of South Dakota's population are Native Americans.

"There has been a very chequered past with the School of Mines," says James Rattling Leaf, an environmental scientist at Sinte Gleska University on the Rosebud Indian Reservation. "Building scientific relationships with them is very tough." By contrast, he says, LBNL scientists have been much more inclusive.
Late last year, the NSF commissioned a peerreview panel to examine DUSEL education and outreach to Native Americans. But project officials didn't share the full results with the cultural advisory committee's Native American members until Nature began enquiring. The document says that more Native American representation was needed for the programme to "deliver its true promise"; it went on to say that a real partnership must be created, and "DUSEL should fully integrate the cultural advisory committee" into planning.

Jon Kotcher, who manages the project for the NSF, says the chance to work with Native Americans is an "exciting opportunity". But DUSEL is still in its early stages, and negotiations take time.

"Everything is going a lot slower than I had hoped," says Jeffrey Henderson, a physician from the Lakota tribe who sits on the cultural advisory committee and is director of the Black Hills Center for American Indian Health in Rapid City. For instance, last spring the South Dakota Science and Technology Authority, which oversees the planned surface laboratory at DUSEL, announced a request for unfunded research proposals. Henderson submitted a proposal to study miners' health, but says he did not hear back. The authority declined to comment.

At a March cultural advisory meeting, project officials gave a presentation on improving Native American educational opportunities through DUSEL. But there was no mention that the School of Mines was no longer working with Rattling Leaf on this type of outreach.

Geological engineer William

Roggenthen, the School of Mines' co-principal investigator for DUSEL, says he thinks the school has "really good connections" with some tribal schools. "My institution is committed to doing more," he says.

To learn more about this effort, Nature sought to interview other scientists and staff, but they declined to talk, for fear, they said, of retaliation from administrators (see 'Sex scandal allegations surface at South Dakota school').

Campbell tried to smooth over relationships by seeking a tribal blessing for DUSEL. Henderson requested one from a highly respected traditional healer from the nearby Pine Ridge Reservation. The healer declined, saying that despite its good intentions, DUSEL is another exploitation of Mother Earth. 